\title{
Two Genes Controlling the Conversion from Flavanonol to Anthocyanidin in Sepals of Genus Aquilegia
}

\author{
Masao Bessho \\ Faculty of .1griculture, Tamagawa Unizersity, Machida, Tokyo 194
}

\begin{abstract}
Summary
In order to make clear the conversion process from flavanonol to anthocyanidin, flavonoid components in sepals of Aquilegia flabellata with white flowers ( $F \mathrm{w}$ ) and 1. hybrida cv. McKana s Giant with creamy white flowers (Mw) were analysed. Isovitexin and populin were identified in both $F$ w and Mw while lcucopelargonidin existed only in $\mathrm{Mw}$. $\mathrm{F}_{1}$ hybrids between $\mathrm{Fw}$ and $\mathrm{Mw}$ showed blue-violet sepals and $\mathrm{F}_{2}$ progeny showed two-gene segregation of sepal coloration. Thus the conversion process is controlled by two genes. Onc recessive gene of fiw controls the reduction of flavanonol and the other recessive gene of $\mathrm{Mw}$ controls the dehydration of leucoanthocyanidin. Complementation of these two genes enables the synthesis of anthocyanidin in $F_{1}$ hybrids.
\end{abstract}

\section{Introduction}

Genes controlling flower color expression and the enzymes related to flavonoid metabolism have been studied by many researchers and the pathway of anthocyanidin synthesis have been well explained by Grisebach (3) and Wong (11). However, the pathway from flavanonol to anthocyanidin is still obscure, although there have been a few reports on the conversion process $(4,6,9,10)$.

Recently, from feeding experiments of ${ }^{3} \mathrm{H}-$ labelled leucopelargonidin to petals of two white mutant lines of Mathiola incana. Heller et al.(5) supposed that there were two steps in the conversion of flavanonol to anthocyanidin and the two steps should be controlled by two different genes, one controlling an enzyme which reduces flavanonol and the other controlling a dehydration of leucoanthocyanidin into anthocyanidin.

In order to make clear the conversion steps from flavanonol to anthocyanidin, the author analysed flavonoid components in sepals of a strain of Aquilegia flabellata Sieb. et Zuce. with white sepals and a strain of 1 . hybrida Hort. cv. McKana's Giant with creamy white sepals, because those strains produced $F_{1}$ hybrids having blue-violet colored sepals in which Received for publication August 15, 1986. anthocyanidin was synthesized.

\section{Materials and Methods}

Two strains of Aquilegia flabellata, one of which had white flowers $\left(F_{w}\right)$ and the other had blue-violet ordinal flowers $(F b)$, and a strain with creamy white flowers (Mw) of $A$. hybrida cv. McKana's Giant were used for the experiments. $F_{1}$ and $F_{2}$ progeny between $F_{\mathrm{w}}$ and $\mathrm{Mw}$ were also used for investigation of heredity of flavonoids. For the analysis of flavonoids, only sepals of the flowers were used.

The coloration of sepals was compared by a color difference meter (ND-101 I)P, Nippon Denshoku Kohgyoh Co.). Absorption spectra of fresh scpals were measured by an integrating sphere attachment to Shimazu UV-240 apparatus.

The sepals of $\mathrm{F}_{\mathrm{w}}, \mathrm{Mw}$ and the $\mathrm{F}_{1}$ hybrid, $40 \mathrm{~g}$ fresh weight each, were collected and extracted with ca. $400 \mathrm{ml}$ of boiling methanol. The methanolic extract was evaporated at reduced pressure, the residue was extracted with hot water. The extract was shaken in a separating funnel with ether and subsequently with ethyl acetate. The ethyl acetate extract was evaporated to dryness, dissolved in a small volume of methanol and stored in a refrigerator at $4^{\circ} \mathrm{C}$. The UVV absorption spectrum in a part of the last methanolic solution was measured. The 
remaining methanolic solution was examined by two-dimensional thin layer chromatography (Merck DC-Alufolien cellulose Art. 5552) using two kinds of solvents, $\mathrm{n}$-butanol: acetic acid: water $(6: 1: 2, \mathrm{v} / \mathrm{v})$ and $15 \%$ acetic acid. The flavonoid compounds were separated by large scale cellulose thin layer chromatography $(20 \times 20 \mathrm{~cm})$ using the above solvents. The method of Mabry et al.(8) was used for identification of flavonoids. Authentic samples were supplied by Dr. M. Hasegawa. The sample ot leucopelargonidin used in this experiment was prepared by reduction of aromadendrin with sodium borohydride.

\section{Results and Discussion}

The L. a. b. value of Mw was closer to $y$ axis than that of $\mathrm{Fw}_{w}$ (Fig. 1). This means that the coloration of $\mathrm{Mw}$ is more yellowish than that of $F_{w}$. The $F_{1}$ hybrid and $\mathrm{Fb}$ were plotted in the fourth quadrant and showed blue-violet sepals.

The absorption spectra of fresh sepals of $F_{w}$, $\mathrm{Mw}$ and $\mathrm{F}_{1}$ hybrids were compared in Fig. 2. $\mathrm{F}_{\mathrm{W}}$ had a maximum absorption at $327 \mathrm{~nm}$ and Mw had a maximum at $336 \mathrm{~nm}$. The spectrum of $\mathrm{Mw}$ showed a slight shoulder at $360-370 \mathrm{~nm}$ which was not observed in the $F_{w}$ spectrum; this shoulder might be caused by the presence of flavonol. $F_{1}$ hybrids and $\mathrm{Fb}$ had three $\mathrm{ab}$ sorption maxima (533, 575 and $628 \mathrm{~nm}$ ) in the visible region, which were caused by anthocyanins.

The absorption spectra of ethyl acetate soluble portions in hot methanol extracts are

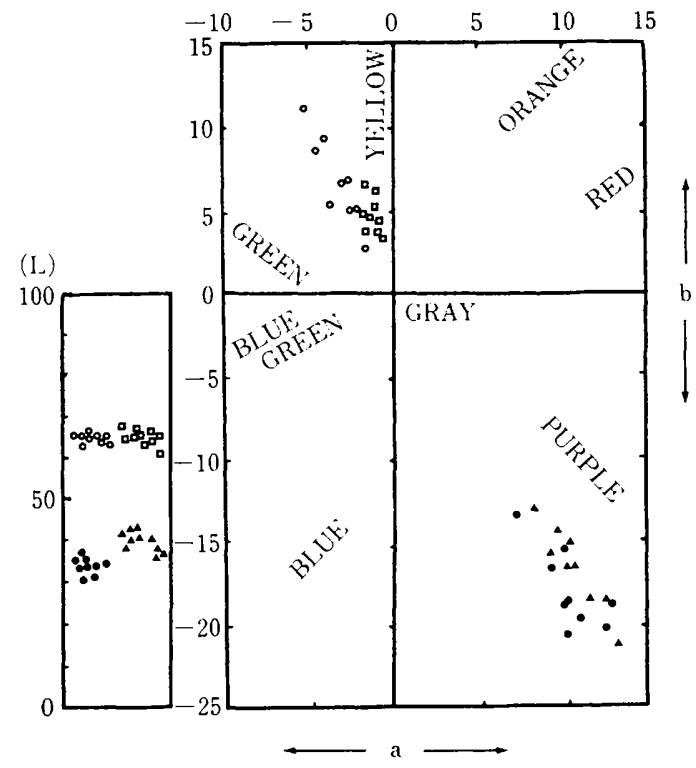

Fig. 1. L. a. b. values of sepals measured by color difference meter. $O: \mathrm{Fw}_{\mathrm{w}} \square: \mathrm{Mw}, \bigcirc: \mathrm{Fb}$, $\Delta$ : $F_{1}$ hybrids.

shown in Fig. 3. $\mathrm{F}_{\mathrm{w}}$ had two absorption peaks at 293 and $328 \mathrm{~nm}$ which were similar to that of chlorogenic acid (296 and $327 \mathrm{~nm}$ ), while $\mathrm{Mw}$ had similar absorption maxima to a group of flavones (270 and $333 \mathrm{~nm}$ ).

From the above results, it is clear that two kinds of white flowers of $\mathrm{Fw}_{\mathrm{w}}$ and $\mathrm{Mw}$ differ each other in tint, and the soluble compounds in hot methanol extracts of $\mathrm{F}_{\mathrm{w}}$ differ qualitatively and quantitatively from those of $\mathrm{Mw}$. In the next experiment, ethyl acetate soluble

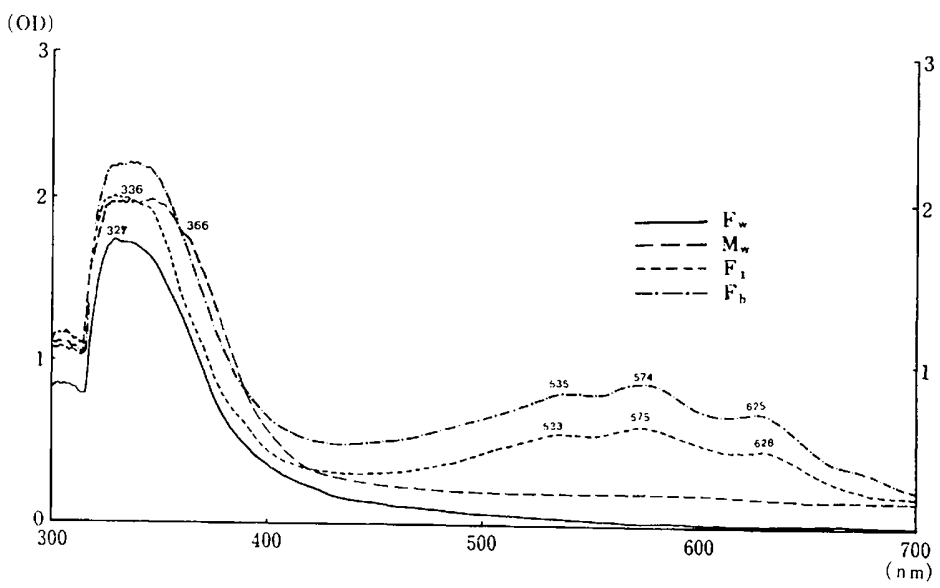

Fig. 2. Absorption spectra of sepals measured by integrating sphere. 


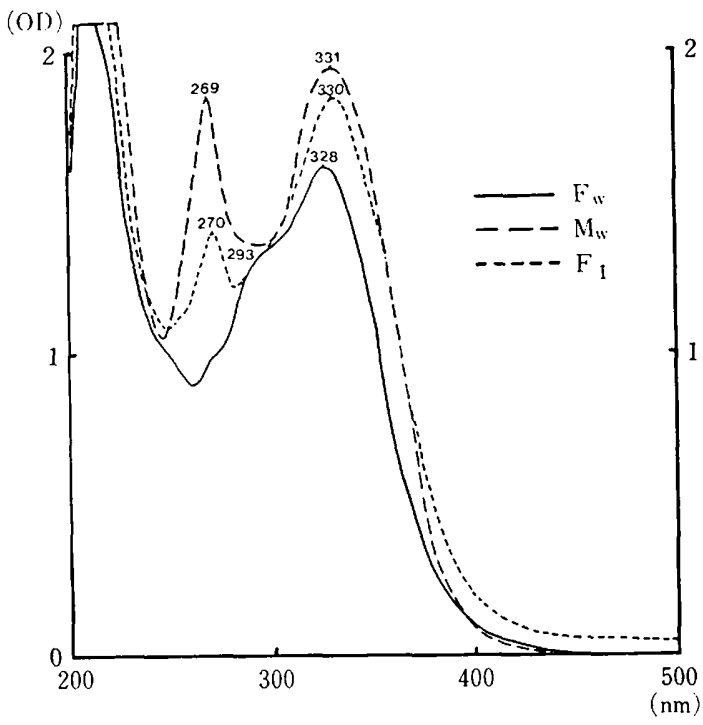

Fig. 3. Absorption spectra of ethyl acetate soluble portions.

compounds of $\mathrm{Fw}_{\mathrm{w}}, \mathrm{Mw}$ and $\mathrm{F}_{1}$ hybrids were separated by two-dimensional chromatography (Fig. 4), and the main spots on the chromatograms were identified by comparison with sample substances (Table 1). Consequently, apigenin-6-C-glucoside (isovitexin) belonging to a group of flavones, and kaempferol-7-0glucoside (populin) belonging to a group of flavonols, were identified as flavonoids in either $\mathrm{Fw}, \mathrm{Mw}$ or $\mathrm{F}_{1}$ hybrids. Caffeic acid, $p$-coumaric acid and ferulic acid were confirmed by thin layer chromatography after hydrolysis, and compounds of spot Nos. 35, 40,42, 43, $53,54,56$ and 57 were presumed to be respec-

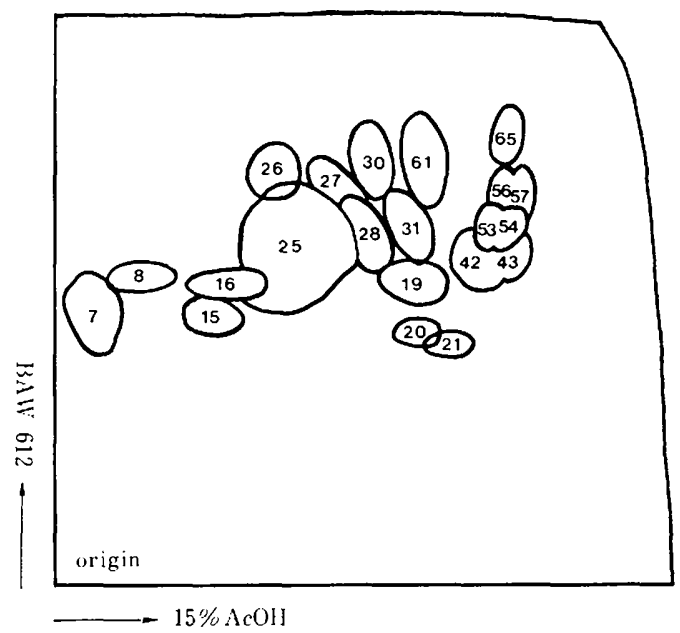

Fig. 4. Two dimensional chromatograms of ethyl acetate soluble portion in $\mathrm{Mw}$. The spots were numbered for cunvenience.

tive derivatives of the above hydroxy-cinnamic acids. From the area of each spot using automatic area meter, $\mathrm{F}_{\mathrm{W}}$ had a low content of flavonoids but a high content of organic acid esters. On the contrary, $\mathrm{Mw}$ had a high content of flavonoids but a low content of organic acid esters. It has been reported in garden snapdragon (Antirrhinum majus) that the albino flowers with semitransparent white petals did not have flavonoids, although the petals had accumulated a lot of esters of $p$-coumaric acid and caffeic acid(2). The white sepals of $\mathrm{F}_{\mathrm{w}}$ had a low content of flavonoids and a high content of organic acid esters like the albino flowers of garden snapdragon. On the contrary,

Table 1. Characteristics of compounds isolated from sepals of $\mathrm{F}_{\mathrm{w}}, \mathrm{Mw}_{\mathrm{w}}$ and $\mathrm{F}_{1}$ hybrids.

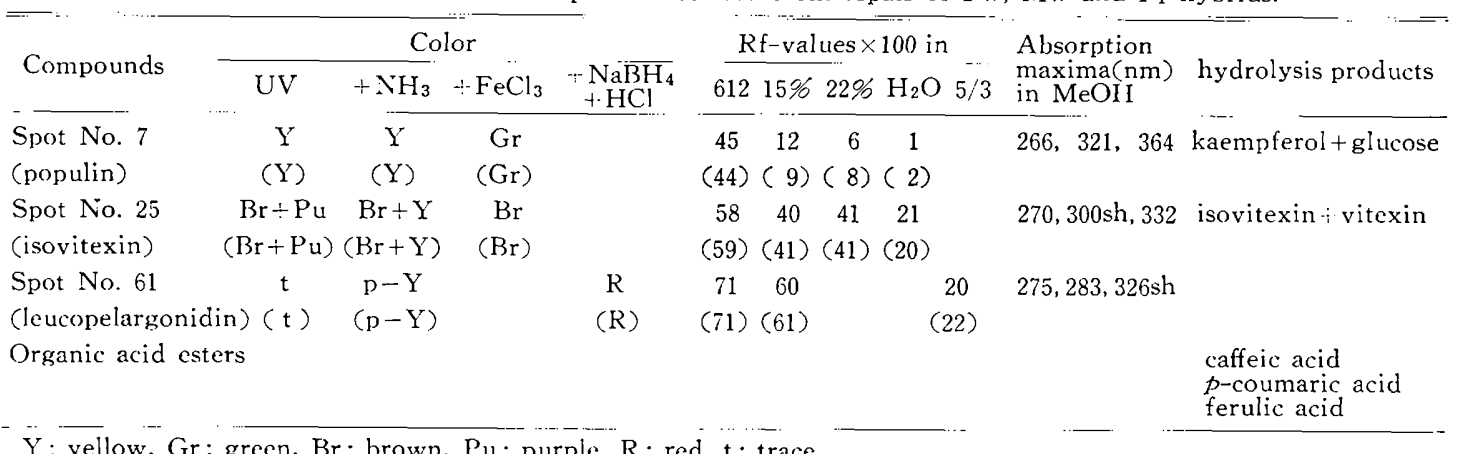
$612:$ n-butanol/acetic acid/water $(6: 1: 2)(\mathrm{v} / \mathrm{v}), 15 \%: 15 \%$ acetic acid, $22 \%: 22 \%$ isopropyl alcohol, $\mathrm{H}_{2} \mathrm{O}:$ water, $5 / 3:$ nitrometane/methanol $(5: 3)(\mathrm{v} / \mathrm{v})$ (used polyamide TLC).

Colors and $\mathrm{Rf}$-values in parentheses indicate those of authentic samples. 
creamy white sepals of $\mathrm{Mw}$ showed slight yellow coloration due to accumulation of flavone and flavonol.

As populin was produced, it is certain that two kinds of white flowers had the ability to synthesize flavanonol, an intermediate of anthocyanidin (Fig. 5). But, because of absence of anthocyanin, it is presumed that a genetic block exists in the process from flavanonol to anthocyanidin. Compounds in the ethyl acetate soluble portion were developed on cellulose TLC. The spots on this TLC were reduced by sodium borohydride and then the plate was exposed to $\mathrm{HCl}$ gas. Consequently, spot No. 61 (Fig. 4) which was specific only for extract of $\mathrm{Mw}$ changed color to red. The reaction suggests that spot No. 61 contains a kind of flavanonol or leucoanthocyanidin(1). After purification, the compound in spot No. 61 was determined as leucopelargonidin (Table 1). Thus $\mathrm{Mw}$ has the ability to reduce flavanonol to leucoanthocyanidin. Leucoanthocyanidin can be chemically changed to anthocyanidin by dehydration. In the feeding experiment to petals of Matthiola incana, ${ }^{3} \mathrm{H}$-labelled leucopelargonidin was converted to ${ }^{3} \mathrm{H}$-labelled pelargonidin(5). The $\mathrm{F}_{1}$ hybrid of $\mathrm{Mw}$ with $F_{W}$ produced anthocyanidin. Therefore, it appears that $\mathrm{Fw}_{\mathrm{w}}$ is able to convert leucoanthocyanidin into anthocyanidin. The present results mean that the blocking parts of $F_{W}$ and $\mathrm{Mw}$ are the process from flavanonol to leucoanthocyanidin and that from leucoanthocyanidin, respectively.

Sticklands and Harrison(10) in Antirrhinum majus, Kho and Bennink(6) and Kho et al. (7) in Petunia hybrida supposed that the conversion from flavanonol to anthocyanidin was controlled by one gene named $P a l$ and $A n 1$, respectively. However, this process consisted of two steps, one being reduction and the other, dehydration. As mentioned earlier,
Table 2. Segregation of $F_{2}$ progenies in sepal color.

\begin{tabular}{|c|c|c|c|c|}
\hline$F_{2}$ strains from & colored & white & $\chi^{2}-$ value $(9: 7)$ & P. \\
\hline $\mathrm{Mw} \times \mathrm{Fw}$ & 30 & 21 & 0.137 & 0.71 \\
\hline $\mathrm{F}_{\mathrm{w}} \times \mathrm{Mw}$ & 15 & 18 & 1.561 & 0.21 \\
\hline Total & 45 & 39 & 0.245 & 0.61 \\
\hline
\end{tabular}

Heller et al. (5) suggested that the process from flavanonol to anthocyanidin consisted of two steps and was controlled by two genes.

The flower color segregation in $\mathrm{F}_{2}$ progenies from $\mathrm{Fw}_{\mathrm{w}}$ times $\mathrm{Mw}$ and the goodness of fit in $\chi^{2}$-test are shown in Table 2. The $\mathrm{F}_{2}$ individuals were separated into two groups by their sepal colors, viz. colored and white, demonstrating a good fit to a ratio of two-gene segregation $(9: 7)$.

It can be concluded that two genes participate in two kind of blocks in $\mathrm{Fw}$ and $\mathrm{Mw}$. One gene controlling the reduction of $-\mathrm{CO}-$ radical in flavanonol to leucoanthocyanidin exists in $\mathrm{Mw}$, while the other gene controlling the dehydration of leucoanthocyanidin exists in $\mathrm{Fw}$ as shown in Fig. 5. The complement of these two genes prompts the synthesis of anthocyanidin in $F_{1}$ hybrids and then the sepals of $F_{1}$ hybrids express blue-violet color. Thus, the presumption of Heller et al. (5) was confirmed in the present experiments.

\section{Acknowledgement}

The author wishes to express gratitude to Dr. Masao Hasegawa and Prof. Tetsuo Nakajima of Tamagawa University for their profitable guidance. The author also thanks Dr. M. Hasegawa for his kind supply of authentic samples.

\section{Literature Cited}

1. Eigen, E., M. Blitz and E. GunsberG. 1957. The detection of same naturally occuring flavanone compounds on paper chromatograms. Arch. Biochem. Biophys. 68: 501-

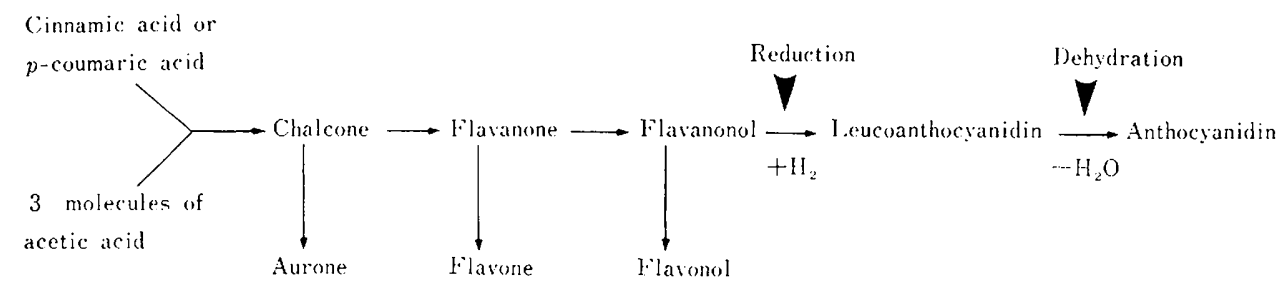

Fig. 5. The pathway of flavonoid biosynthesis. 
502.

2. GeIssman, T. A. and J. B. HARborne. 1955. The chemistry of flower pigmentation in Antirrhinum majus. The albino (--mm $--n n)$ form. Arch. Biochem. Biophys. 55: $447-454$.

3. GrisebACH, H. 1967. Biosynthesis patterns in microorganisms and higher plants. p. 131, John Wiley and Sons, Inc., New York.

4. HARRISON, B. J. and R. G. STICKLAND. 1974. Precursors and genetic control of pigmentation. 2. Genotype analysis of pigment controlling genes in acyanic phenotypes in Antrrihinum majus. Heredity 33: 112-115.

5. Heller, W., L. BRITSCH, G. FORKMANN and IH. GRISEBACH. 1985. Leucoanthocyanidins as intermediates in anthocyanidin biosynthesis in flowers of Matthiola incana $R$. Br., Planta 163: 191-196.

6. KHO, K. F. F. and G. J. H. BENNINK, 1975. Anthocyanin synthesis in a white flowering mutant of Petunia hybrida by a complementation technique. Planta 127: 271-279.
7. KHO, K. F. F., A. C. BOLSMAN-LONWEN, J. C. VLIK and G. J. H. BENNINK. 1977. Anthocyanin synthesis in a white flowering mutant of Petunia hybrida. Planta 135: 109-118.

8. Mabry, T. J., K. R. MARKhiAM and M. B. THOMAS. 1970. The synthematic identification of flavonoids. Springer-Verlag, New York. p. 354.

9. SPribille, R. and G. FORKMANN. 1982. Genetic control of chalcone synthase activity in flower of Antirrhinum majus. Phytochem. istry $21: 2231-2234$.

10. StickLAND, R. G. and B. J. HARRISON. 1974. Precursors and genetic control of pigmentation. 1. Induced biosynthesis of pelargonidin, cyanidin and delphinidin in Antir. rhinum majus. Heredity 33: 108-112.

11. WONG, E. 1976. Biosynthesis of flavonoids. p. 464-526. In : T.W. Goodwin(ed.) Chemistry and biochemistry of plant pigments (2nd ed. Vol. 1) Academic Press, London.

\section{オダマキのがく片に㧍けるフラバノノールからアントシアニジンへの \\ 転換に関与する 2 遺伝子.}

別 所 雅 犬

汰川大学榓学部 194 東京都町田标

\begin{abstract}
摘 要
フラバノイールからアントシアニジンへの転換過程を 叮らかにするために，紫肯色花を呈する $\mathrm{F}_{1}$ 雑種の屾視 である，ミヤーオダマキ(Aquilegia flabellata)白色花 と, A. hybrida 品種マッカナジャイアント白芯花のフ ラボノイド成分を分析比䡌した．2種類の白色花ともイ ソビテキシンとポプリンを持つが、マッカナジャイアン 卜白色花には，ロイコペラルゴニジンが特別に存在し

った.したがって，ミけマオダマキ丢色化はフラバノ， ールからロイコアントシアニジンとの間で, マッカナジ ヤイアント白色花は，ロイコアントシアニジンからアン トシアニジンの間で，それぞれ遗伝似にブロックされて いると考えられる． $F_{1}$ 雑種においては，この 2 遺伝子 が補足し合い，アントシアニジンを生涟し，紫青色花を 号したと考えられる.
\end{abstract} た. $\mathrm{F}_{2}$ の分離比よりこの転换過程は 2 遗伀子支配であ 